\title{
Bioactive Titanate Layers Formed on Titanium and Its Alloys by Simple Chemical and Heat Treatments
}

\author{
Tadashi Kokubo* and Seiji Yamaguchi
}

Department of Biomedical Sciences, College of Life and Health Sciences, Chubu University 1200 Matsumoto-chow, Kasugai, Aichi 487-8501 Japan

\begin{abstract}
To reveal general principles for obtaining bone-bonding bioactive metallic titanium, Ti metal was heat-treated after exposure to a solution with different $\mathrm{pH}$. The material formed an apatite layer at its surface in simulated body fluid when heat-treated after exposure to a strong acid or alkali solution, because it formed a positively charged titanium oxide and negatively charged sodium titanate film on its surface, respectively. Such treated these Ti metals tightly bonded to living bone. Porous Ti metal heat-treated after exposure to an acidic solution exhibited not only osteoconductive, but also osteoinductive behavior. Porous Ti metal exposed to an alkaline solution also exhibits osteoconductivity as well as osteoinductivity, if it was subsequently subjected to acid and heat treatments. These acid and heat treatments were not effective for most Ti-based alloys. However, even those alloys exhibited apatite formation when they were subjected to acid and heat treatment after a $\mathrm{NaOH}$ treatment, since the alloying elements were removed from the surface by the latter. $\mathrm{The} \mathrm{NaOH}$ and heat treatments were also not effective for Ti-Zr-Nb-Ta alloys. These alloys displayed apatite formation when subjected to $\mathrm{CaCl}_{2}$ treatment after $\mathrm{NaOH}$ treatment, forming Ca-deficient calcium titanate at their surfaces after subsequent heat and hot water treatments. The bioactive Ti metal subjected to $\mathrm{NaOH}$ and heat treatments has been clinically used as an artificial hip joint material in Japan since 2007. A porous Ti metal subjected to $\mathrm{NaOH}, \mathrm{HCl}$ and heat treatments has successfully undergone clinical trials as a spinal fusion device.
\end{abstract}

Keywords: Artificial hip joint, bioactive Ti, bone-bonding ability, osteoconduction, osteoinduction, spinal fusion device, titanium metal, Ti-based alloy.

\section{INTRODUCTION}

Various kinds of ceramic such as bioglass, sintered hydroxyapatite, and sintered $\beta$-tricalcium phosphate have been found to bond to living bone. They are being already clinically used as important bone substitutes. However, they cannot be used under load-bearing conditions, since their mechanical strength is not equivalent to that of human cortical bone. Under load-bearing conditions, only metallic materials such as stainless steel, Co-Cr-Mo alloys, and titanium (Ti) metal and its alloys are being used as bonerepair materials. However, such materials generally do not bond with living bone and hence their fixation is not stable over long period. In order to confer a bone-bonding capacity to metallic materials, calcium phosphates such as hydroxyapatite have been coated onto their surfaces [1]. However, in most cases the coated layers are not stable in the living body. In contrast to this, to confer bone bonding to a metallic material, we sought to induce apatite formation on the metallic surface in the living body. In the present paper, simple chemical and heat treatments are discussed designed to form a titanate layer that induces apatite formation on the

*Address correspondence to the author at the Department of Biomedical Sciences, College of Life and Health Sciences, Chubu University, 1200 Matsumoto-chow, Kasugai, Aichi 487-8501 Japan; Tel: 81-75-951-164; Fax: 81-75-957-164; E-mail: kokubo@isc.chubu.ac.jp surfaces of Ti metal and its related metals in the living body, as well as their clinical applications.

\section{BACKGROUND OF THE PRESENT CONCEPT}

Previously, the present authors reported that A-W glassceramics precipitating apatite and wollastonite in a glass matrix bond to living bone through an apatite layer that formed on the surface in the living body. This apatite layer can be reproduced even in an acellular simulated body fluid (SBF) with ion concentrations nearly equal to those of human blood plasma [2]. In addition, it was found that bioglass and sintered hydroxyapatite also bond to living bone through this apatite layer formed in the living body, and that this layer is reproduced even in SBF [2]. Based on these findings, it was postulated that materials with surface apatite formation in SBF also have this capacity in the living body and are able to bond to living bone through the apatite layer.

Subsequently, a titania gel prepared by a sol-gel method was shown to form apatite on its surface in SBF [3].This indicates that $\mathrm{Ti}$ metal and its alloys also form apatite on their surfaces in SBF as well as in the living body, and bond to living bone through the apatite layer when their surfaces are appropriately modified. Based on this hypothesis, various kinds of surface modification of Ti metal and its alloys have been proposed for inducing apatite formation and/or bone 
bonding capability. Ion implantation [4-6], hydrothermal treatments [7-12], electrochemical reactions [13-22] are some examples of these surface modifications. However, they require special equipment and are not readily applicable to large-scale devices of complicated shape or comprised of porous material. In contrast to these methods, simple chemical and heat treatments do not require any special equipment and hence are applicable to a broad range of shapes and materials.

It was reported, that even simple heat treatment is effective to induce apatite formation, as in the case of $\mathrm{Ti}$ metal subjected to magnetron sputtering [23] and Ti-15Zr$4 \mathrm{Ta}-4 \mathrm{Nb}$ alloy to micro-grooving [24]. It was also reported, that even simple chemical treatment by $\mathrm{H}_{2} \mathrm{SO}_{4}$ [25], $\mathrm{HNO}_{3}$ $[26,27], \mathrm{HF}[28,29], \mathrm{H}_{2} \mathrm{SO}_{4} / \mathrm{HCl}[30,31]$ or $\mathrm{H}_{2} \mathrm{O}_{2} / \mathrm{TaCl}_{2}$ [32] solutions is effective to induce apatite formation and/or bone bonding on Ti metal and its alloys. It was also reported, that heat treatment after chemical treatment with $\mathrm{H}_{2} \mathrm{O}_{2}[33,34]$, $\mathrm{H}_{2} \mathrm{O}_{2} / \mathrm{HCl}$ [35] or $\mathrm{H}_{2} \mathrm{SO}_{4} / \mathrm{H}_{2} \mathrm{O}_{2}$ [36] solutions are effective for inducing apatite formation and/or bone bonding of $\mathrm{Ti}$ metal and its alloys. However, these studies have not been performed systematically. Consequently, the general principles governing the apatite formation induced by these treatments are not well understood. We have systematically investigated the chemical and heat treatments effective for inducing apatite formation and bone bonding in $\mathrm{Ti}$ and its alloys. The results of these investigations are summarized and reviewed below. Chemical and heat treatments for inducing apatite formation are also mentioned for some metals other than Ti metal.

\section{APATITE FORMATION ON Ti AS A FUNCTION OF THE SOLUTION pH}

If $\mathrm{Ti}$ metal is exposed for 24 hours to aqueous solutions of $\mathrm{HCl}$ or $\mathrm{NaOH}$ with $\mathrm{pH}$ that is changed from almost 0 to 14 at $60{ }^{\circ} \mathrm{C}$, and then heat-treated at $600{ }^{\circ} \mathrm{C}$ for $1 \mathrm{~h}$, it forms apatite on its surface in SBF. However, this does not happen when exposed to solutions of intermediate $\mathrm{pH}$ levels, as shown in Fig. (1) [37]. The Ti metal formed micrometer- and nanometer-scale roughness, respectively on its surface, when exposed to strongly acidic or alkaline solutions as shown in Fig. (2) [37]. It formed only rutile phase on its surface upon exposure to solutions with $\mathrm{pH}$ values below 13, whereas sodium titanate accompanied by a small amount of rutile was formed at $\mathrm{pH}$ above 13. In view of these facts, apatite formation on the surface of $\mathrm{Ti}$ metal can be ascribed to neither specific surface roughness nor the presence of a specific crystalline phase. When the Zeta potential of the Ti metal subjected to the solution and heat treatments were measured in a $\mathrm{NaCl}$ solution it exhibited a high positive or negative potential upon exposure to strongly acidic or

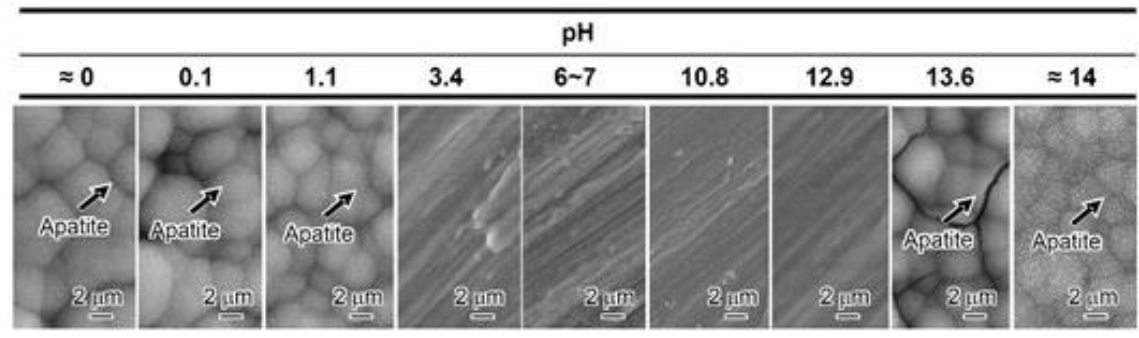

Fig. (1). SEM photographs of surfaces of Ti metal soaked in SBF for 3 days after heat treatment following exposure to solutions with different $\mathrm{pH}$ values. Reproduced from Ref. [37].

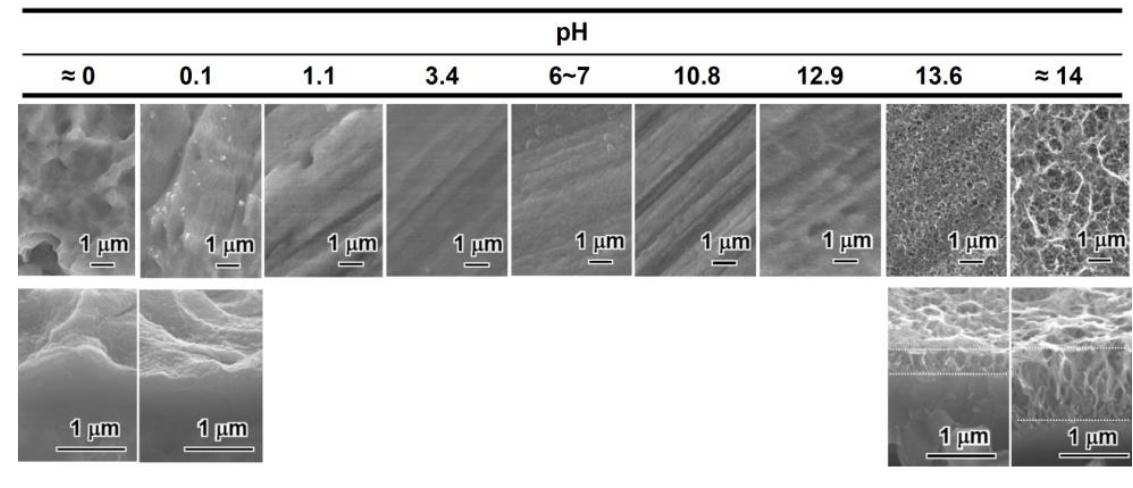

\begin{tabular}{lcc}
\hline $\begin{array}{l}\text { Micrometer-scale } \\
\text { roughness }\end{array}$ & Surface morphology & \\
\hline \hline & Smooth & $\begin{array}{c}\text { Nanometer-scale } \\
\text { roughness }\end{array}$ \\
\hline Rutile $\left(\mathrm{TiO}_{2}\right)$ & $\begin{array}{c}\text { Sodium titanate } \\
\left(\mathrm{Na}_{2} \mathrm{Ti}_{6} \mathrm{O}_{13}\right) \\
+\mathrm{Rutile}\left(\mathrm{TiO}_{2}\right)\end{array}$ \\
\hline
\end{tabular}

Fig. (2). SEM photographs of surfaces (top) and cross sections (bottom) of Ti metal heat-treated after exposure to solutions with different pH values, as well as crystalline phases detected on their surfaces. Reproduced from Ref. [37]. 
alkaline solutions, respectively, as shown in Fig. (3) [37]. This indicates that the apatite formation on the surface of the Ti metal is ascribable to the surface charge.

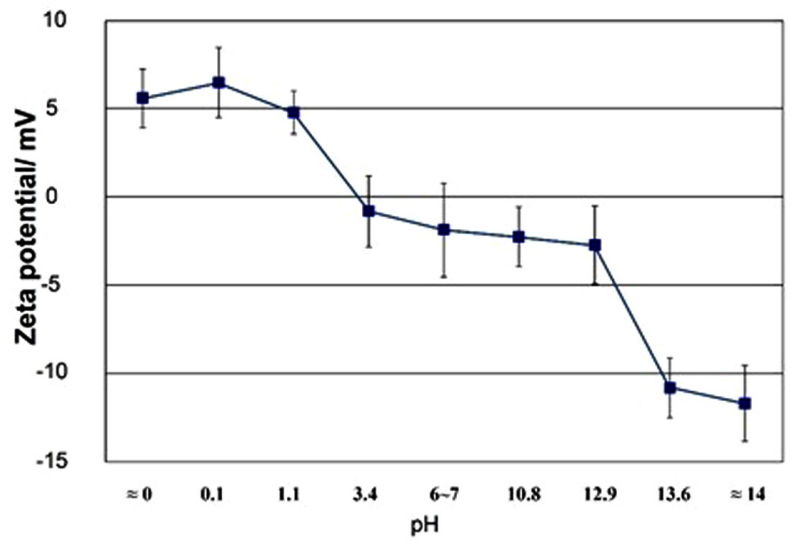

Fig. (3). Zeta potentials of Ti metal heat-treated after exposure to solutions with different $\mathrm{pH}$ values. Reproduced from Ref. [37].

The positively charged surface of the acid-treated $\mathrm{Ti}$ metal may first preferentially adsorb negatively charged phosphate ions in SBF. When phosphate ions accumulate, the surface becomes negatively charged and adsorbs positively charged calcium ions to form apatite as shown in Fig. (4) $[37,38]$. On the other hand, the negatively charged surface of the alkali-treated $\mathrm{Ti}$ metal first preferentially adsorbs positively charged calcium ions and then negatively charged phosphate ions to form apatite, as shown in Fig. (5) $[37,39]$. This sequential absorption of the calcium and phosphate ions on the surface of the Ti metal in SBF were experimentally confirmed by X-ray photoelectron spectroscopy of Ti metal soaked in SBF for different periods of time, and of surfaces exposed to acidic [38] and alkaline $[40,41]$ solutions, respectively.
The Ti metal forms titanium hydrides adsorbed with acid radicals on its surface when exposed to acidic solutions [37, $38,42]$. The titanium hydrides are transformed into titanium oxide adsorbed with acid radicals by heat treatment [37, 38]. The acid radicals dissociate in SBF to produce an acidic environment on the titanium oxide. It has been reported, that titanium oxide is positively charged in an acidic solution, as shown in Fig. (6) [37, 43]. Consequently, the surface of the Ti metal heat-treated after exposure to an acidic solution is positively charged.

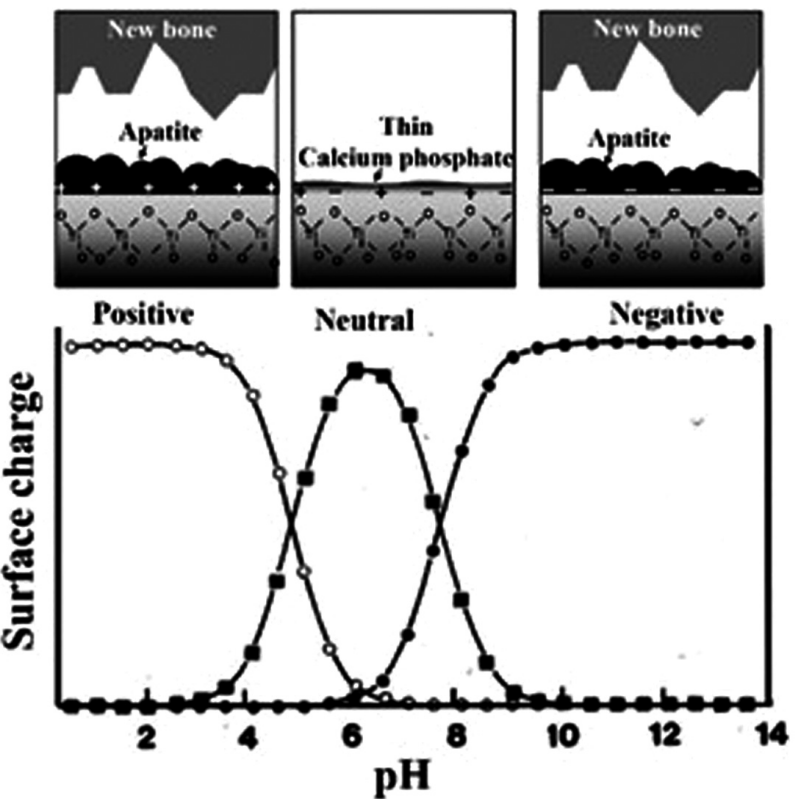

Fig. (6). Surface charges of titanium oxide as a function of $\mathrm{pH}$ of exposed solution. Reproduced from ref. 37. The original data were obtained by calculation based on equilibrium among $\mathrm{H}^{+}$, TiOH, $\mathrm{TiOH}_{2}^{+}$and $\mathrm{TiO}^{-}$by Gold et al. [43].
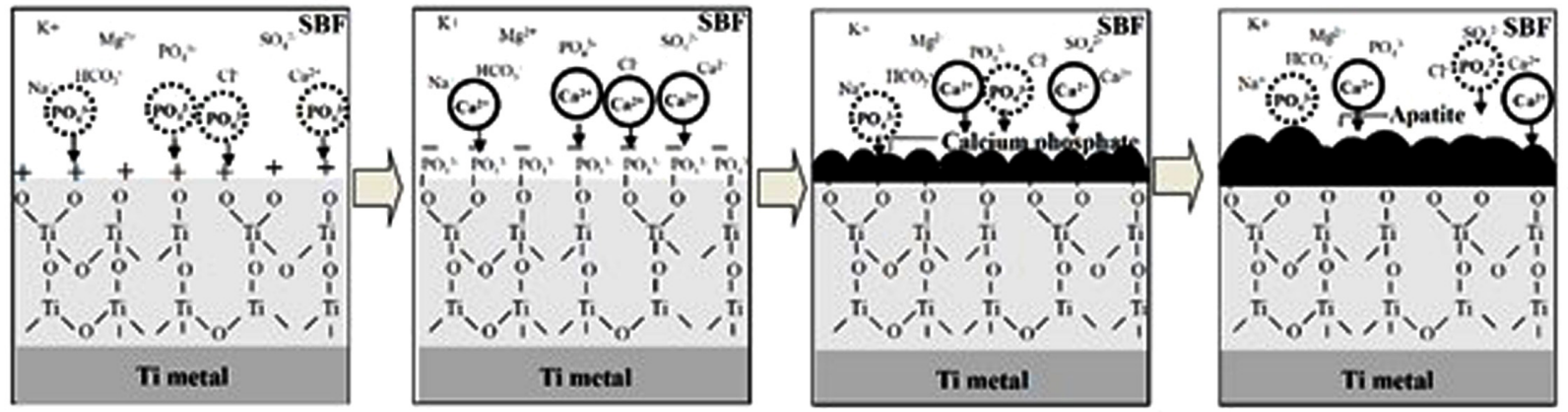

Fig. (4). Process of apatite formation on acid-and heat-treated Ti metal. Reproduced from Ref. [38].

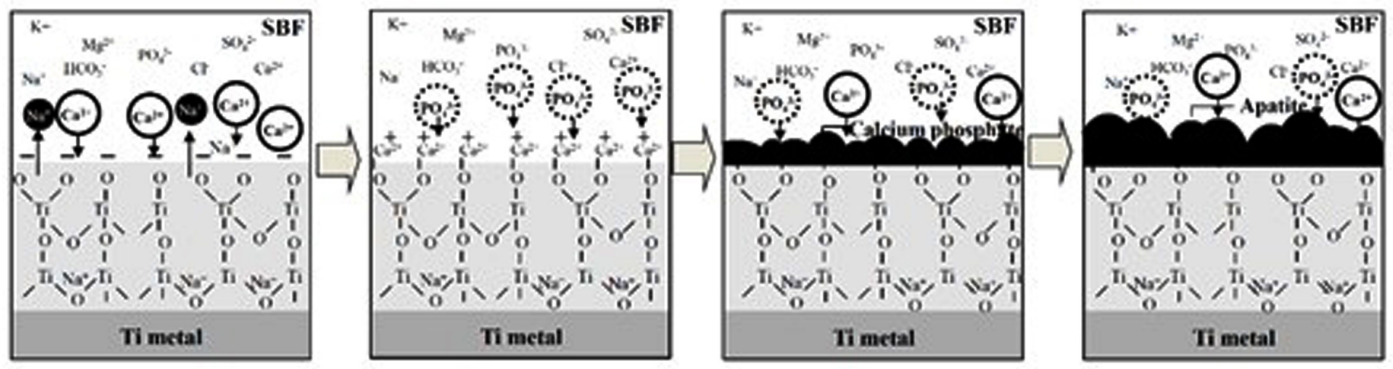

Fig. (5). Process of apatite formation on $\mathrm{NaOH}$-and heat-treated Ti metal. Reproduced from Ref. [39]. 
Likewise, when exposed to a $\mathrm{NaOH}$ solution Ti metal forms sodium hydrogen titanate on its surface, which is transformed into sodium titanate by heat treatment [44]. The sodium titanate releases $\mathrm{Na}^{+}$ions via exchange with $\mathrm{H}_{3} \mathrm{O}^{+}$ ions in SBF to produce an alkaline environment at the titanium oxide. It has been reported, that titanium oxide is negatively charged in an alkaline solution, as shown in Fig. (6) [37, 43]. Consequently, the surface of the Ti metal heattreated after exposure to the alkaline solution is negatively charged.

When the Ti metal was heat-treated after exposure to neutral solutions, it was neither positively nor negatively charged on its surface, as shown in Fig. (3). This indicates that an equal number of positively charged sites and negatively charged sites coexist on its surface. Consequently, negatively charged phosphate ions and positively charged calcium ions are simultaneously adsorbed on its surface so that the respectively charged sites are soon neutralized, as confirmed by XPS [37]. As a result, it forms only a thin calcium phosphate layer, which does not grow into apatite, as shown in Fig. (6).
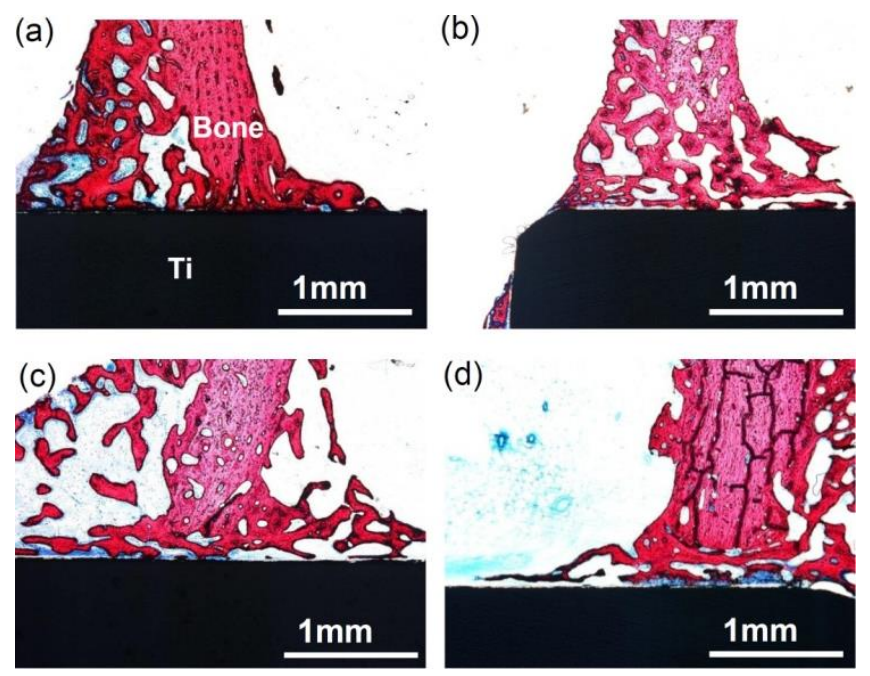

Fig. (7). Optical micrographs of non-decalcified sections of $\mathrm{Ti}$ metals acid-and heat-treated (a), water-and heat-treated (b), aswater-treated (c), and as-acid-treated (d), 4 weeks after implantation into the tibia of rabbits. Reproduced from Ref. [45].

When the Ti metal was not heat-treated after exposure to the solutions, it was neither positively nor negatively charged, independent of the $\mathrm{pH}$ of the solutions. This is because no electrically insulating phase was formed on its surface by the chemical treatment alone, except for sodium hydrogen titanate in the case of the specimens exposed to the solutions with a $\mathrm{pH}$ higher than 13. Consequently, they did not form apatite on their surfaces, except for the Ti metals exposed to the solutions of $\mathrm{pH}$ above 13 [37].

It is thus clear from these results that $\mathrm{Ti}$ metal forms apatite on its surface in SBF upon heat treatment after exposure to strongly acidic or alkaline solutions, since it becomes positively or negatively charged on its surface after these treatments [37]. This predicts that $\mathrm{Ti}$ metal will also form an apatite layer on its surface in the living body and bond to living bone through an apatite layer, when it is heattreated after exposure to a strongly acidic or alkaline solution.

\section{BONE BONDING ABILITY OF Ti METAL AS A FUNCTION OF SOLUTION pH}

A rectangular Ti metal specimen heat-treated at $600{ }^{\circ} \mathrm{C}$ for $1 \mathrm{~h}$ after exposure to a strong mixed acidic solution of $\mathrm{H}_{2} \mathrm{SO}_{4} / \mathrm{HCl}$ at $70^{\circ} \mathrm{C}$ for $1 \mathrm{~h}$ was implanted into the tibia of a rabbit. Within 4 weeks, the specimen came into direct contact with the surrounding bone without any intervening fibrous tissue. However, the specimens that had been heattreated after exposure to only pure water, as well as those not heat-treated after exposure to either water or a strongly acidic solution, were encapsulated by fibrous tissue, as shown in Fig. (7) [45]. When tensile stress was applied to the interface between the specimen, heat-treated after exposure to the strongly acidic solution, and the bone, fracture did not occur at the interface but occurred through the bone.

In the case of dental implants, only sandblasting or acid etching was applied to the Ti metal in most cases, for the purpose of obtaining osteointegration [46]. However, the present results show that bonding of the Ti implant with the surrounding bone cannot be realized without subsequent heat treatment.

When a porous specimen of Ti metal was implanted into the femoral condyle of a rabbit, the specimen that had been heat-treated after exposure to the strongly acidic solution became deeply penetrated by newly grown bone within 3 weeks. However, specimens heat-treated after exposure to only pure water as well as those not heat-treated after exposure to water or acidic solution were only slightly penetrated by newly grown bone, as shown in Fig. (8) [47].
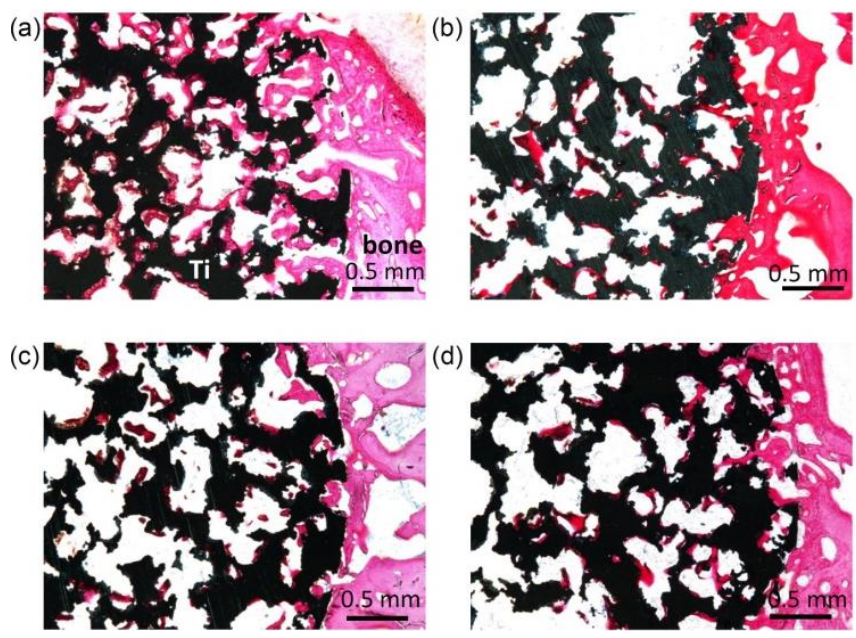

Fig. (8). Optical micrographs of non-decalcified sections of porous Ti metals acid-and heat-treated (a), water-and heat-treated (b), aswater-treated (c), and as-acid-treated (d), 3 weeks after implantation into the femoral condyle of rabbits. Reproduced from Ref. [47].

When identical porous specimens of the Ti metal were implanted into a dorsal muscle of a beagle dog, the specimen 
that had been heat-treated after exposure to a strongly acidic solution formed new bone tissue, ectopically in its porous region, within 12 months. However, specimens heat-treated after exposure to only pure water, as well as those not heattreated after exposure to either water or strongly acidic solution, formed no bone, as shown in Fig. (9) [48]. (a)

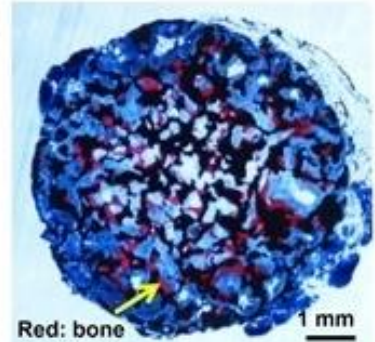

(c)

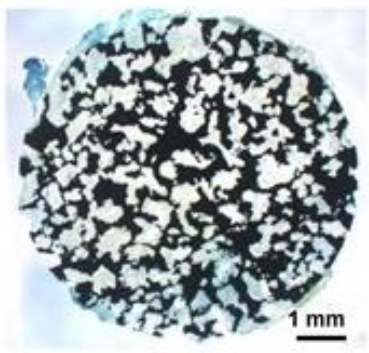

(b)

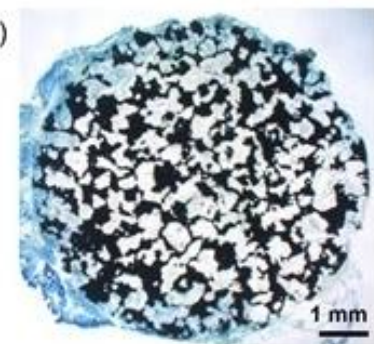

(d)

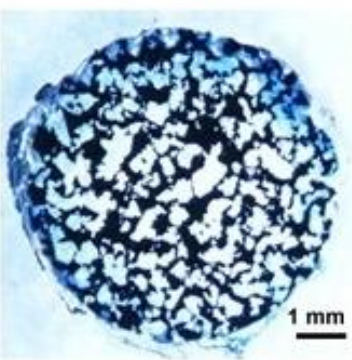

Fig. (9). Optical micrographs of de-calcified sections of porous $\mathrm{Ti}$ metals acid-and heat-treated (a), water-and heat-treated (b), aswater-treated (c), and as-acid-treated (d), 12 months after implantation into the muscle of dogs. Reproduced from Ref. [48].

These results show, that $\mathrm{Ti}$ metal heat-treated after exposure to strongly acidic solution exhibits not only bone bonding ability and osteoconductivity, as expected by apatite formation in SBF, but also osteoinductivity.

Likewise, a rectangular Ti metal specimen, heat-treated at $600{ }^{\circ} \mathrm{C}$ for $1 \mathrm{~h}$ after exposure to a strongly alkaline solution of $5 \mathrm{M} \mathrm{NaOH}$ at $60{ }^{\circ} \mathrm{C}$ for $24 \mathrm{~h}$, and implanted into the tibia of a rabbit was found to form an apatite layer on its surface. The specimen came into contact with the surrounding bone through the apatite layer, without any evident fibrous tissue, within 8 weeks, as shown in Fig. (10) [49]. When a Ti metal rod, heat-treated after exposure the $\mathrm{NaOH}$, was implanted into the medullary canal of the rabbit femur, the specimen could not be pulled out after 12 weeks of implantation without accompanying bone fragments, as shown in Fig. (11) [50].

When a porous specimen of the Ti metal was implanted into a rabbit femoral condyle, the specimen that had been heat-treated after exposure to the $\mathrm{NaOH}$ solution became deeply penetrated by newly grown bone within 4 weeks, whereas a specimen not heat-treated after exposure to water was only slightly penetrated by newly grown bone [51].

When an identical porous specimen of the Ti metal was implanted into the dorsal muscle of a beagle dog, the specimen that had been heat-treated after exposure to the
$\mathrm{NaOH}$ solution also formed a new bone tissue ectopically in its porous structure within 12 months, but only to a small amount [52].
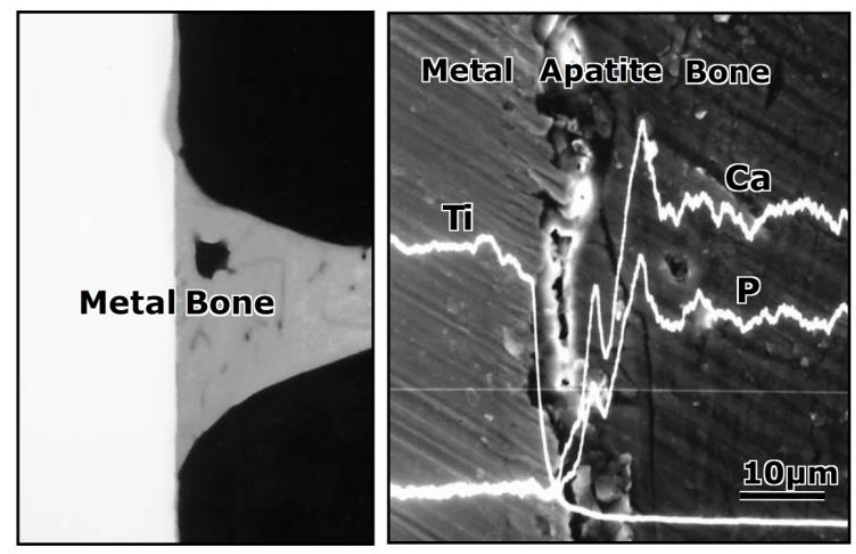

Fig. (10). Contact radiomicrograph (left hand) and SEM photograph (right hand) of Ti metal heat-treated after exposure to $\mathrm{NaOH}$ solution at its interface with the bone, 8 weeks after implantation into the tibia of rabbits. Reproduced from Ref. [49].

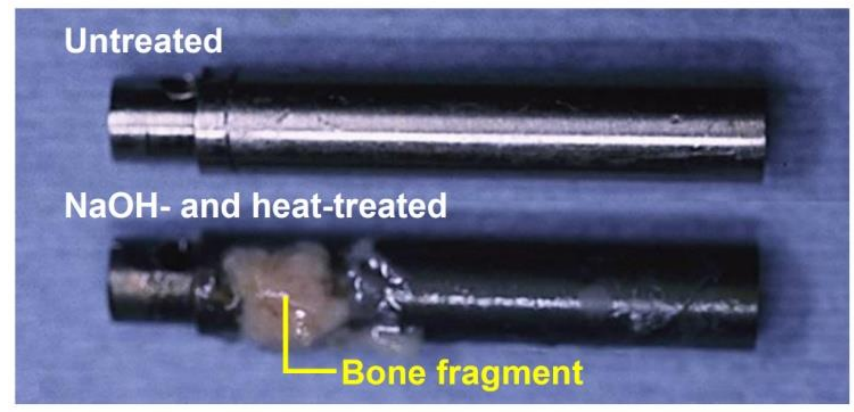

Fig. (11). Titanium metal rod heat-treated after exposure to $\mathrm{NaOH}$ solution, which was pulled out from the medullary canal of a rabbit, 12 weeks after implantation, in comparison with an untreated rod, after Ref. [50].

These results show that a $\mathrm{Ti}$ metal heat-treated after exposure to a strongly alkaline solution exhibits bone bonding ability and osteoconductivity, as expected from the apatite formation on its surface in SBF. However, its osteoinductivity was very small, in contrast with the specimen heat-treated after exposure to a strongly acidic solution.

Tsukanaka et al. recently observed active proliferation and differentiation of osteoblasts around $\mathrm{Ti}$ metal heattreated after exposure to $\mathrm{NaOH}$ solution using fluorescent mouse osteoblasts in vivo [53].

Hence, the general principle governing the bone-bonding capacity of Ti metal is clear as evidenced from these results. A bone-bonding Ti metal can be obtained by simple heat treatment after exposure to a strongly acidic or alkaline solution, since it becomes charged positively or negatively on its surface thus able to form an apatite layer. 


\section{MODIFICATION OF ACID AND HEAT TREATMENT OF Ti AND ITS ALLOYS}

The general principle governing the bone bonding ability of Ti metal described above is also basically valid for Tibased alloys. However, some modification is required of the chemical and heat treatments in order to obtain bone bonding alloys, since the alloying elements tend to disturb the outcome. For example, alloying elements tend to form oxides different from titanium oxide on the surface of the alloys after the acid and heat treatments that suppress apatite formation on their surfaces in either SBF or the living body. In these cases, if the alloys are first exposed to the $\mathrm{NaOH}$ solution to remove the alloying elements from their surfaces, the acid and heat treatments are effective. For example, when Ti-15Zr-4Nb-4Ta alloy was preliminarily exposed to the $\mathrm{NaOH}$ solution, it formed a positively charged titanium oxide layer after $\mathrm{HCl}$ and heat treatments, and subsequently apatite on its surface in SBF [54].

The acid and heat treatments after exposure to a $\mathrm{NaOH}$ solution have some benefits even for pure $\mathrm{Ti}$ metal, since they form a titanium oxide surface layer with a nanometerscale roughness in a highly specific area after these treatments, in contrast with the titanium oxide surface layer with a micrometer-scale roughness produced by direct acid and heat treatments. When the Ti metal is first exposed to a $\mathrm{NaOH}$ solution, it forms a sodium hydrogen titanate surface layer with a nanometer-scale roughness. The sodium hydrogen titanate is transformed into hydrogen titanate by subsequent acid treatment [55] and then into titanium oxide by subsequent heat treatment [56], retaining the nanometerscale roughness on its surface as long as the acid concentration is not too high [57].

The Zeta potential of the surface titanium oxide layer increases with increasing concentration of the acidic solution used to increase apatite formation on its surface in SBF, irrespective of the type of acidic solution used [57].

As described above, porous Ti metal subjected to $\mathrm{NaOH}$ and heat treatment exhibited little osteoinductivity. This might be attributed to the sodium ions released from the sodium titanate surface layer, which increase the local $\mathrm{pH}$ in the narrow space of the pores, suppressing bone formation. When the $\mathrm{HCl}$ and heat treatments were applied to the porous $\mathrm{Ti}$ metal after the $\mathrm{NaOH}$ treatment, a positively charged titanium oxide layer with a nanometer-scale roughness formed on the inner surface of the pore, resulting in the high osteoinductivity shown in Fig. (12) $[52,58,59]$ as well as osteoconductivity, as shown in Fig (13) $[60,61]$. Zhao et al. have independently reported the osteoinductivity of the Ti metal subjected to $\mathrm{NaOH}, \mathrm{HCl}$ and heat treatments [62]. The porous $\mathrm{Ti}$ metal used for this purpose can be produced by sintering of $\mathrm{Ti}$ metal powders containing volatile materials [63] or 3D-selective laser melting of $\mathrm{Ti}$ metal powders $[61,64]$.

\section{MODIFICATION OF NaOH AND HEAT TREATMENT OF Ti AND ITS ALLOYS}

Gil et al. showed that the apatite-forming ability in vitro [65] as well as in vivo [66] and also the bone-bonding of the Ti metal heat-treated after exposure to the $\mathrm{NaOH}$ solution can be increased by preliminary sand-blasting of the $\mathrm{Ti}$ metal.
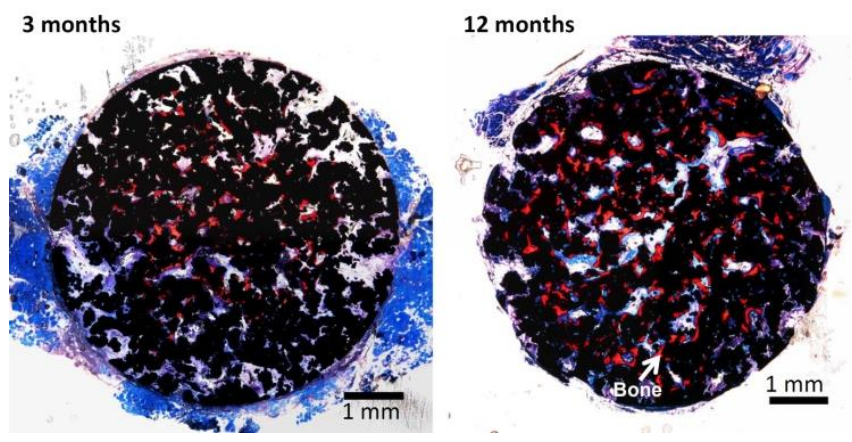

Fig. (12). Optical micrographs of de-calcified sections of porous Ti metal subjected to $\mathrm{NaOH}, \mathrm{HCl}$ and heat treatments, 3 and 12 months after implantation into the muscle of a dog. Reproduced from Ref. [52].
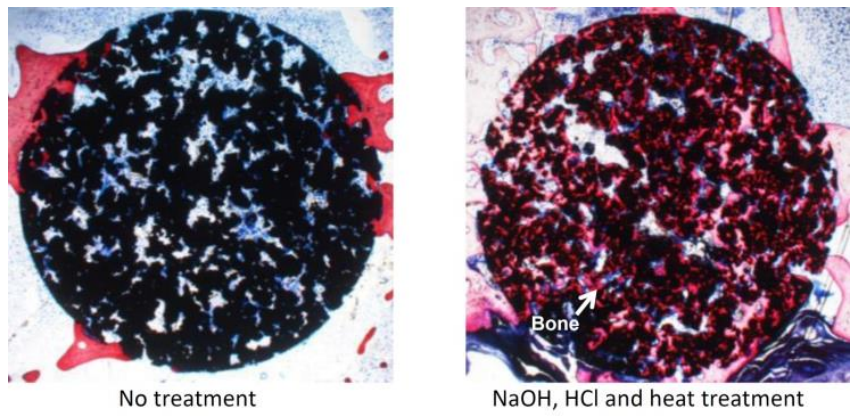

Fig. (13). Optical micrographs of de-calcified sections of porous $\mathrm{Ti}$ metal untreated and subjected to $\mathrm{NaOH}, \mathrm{HCl}$ and heat treatments, 26 weeks after implantation into a rabbit femur, after Ref. [60 and $61]$.

The $\mathrm{NaOH}$ and heat treatments are effective not only for pure Ti metal, but also for conventional Ti-based alloys such as Ti-6Al-4V [67-69], Ti-6Al-2Nb-Ta [67, 69] and Ti$15 \mathrm{Mo}-5 \mathrm{Zr}-3 \mathrm{Al}$ [67, 69]. These alloys induce apatite formation on their surfaces in SBF and bone bonding, since alloying elements such as $\mathrm{Al}, \mathrm{V}$ and Mo are selectively released from the surface by the $\mathrm{NaOH}$ treatment. However, these simple treatments are not effective for certain new kinds of alloy of the type Ti-Zr-Nb-Ta, which are free of elements suspected of cytotoxicity such as $\mathrm{Al}$ and $\mathrm{V}$, since the alloying elements $\mathrm{Zr}, \mathrm{Nb}$ and $\mathrm{Ta}$ are hardly released by the $\mathrm{NaOH}$ treatment, suppressing apatite formation in SBF or the living body [54].

In addition, these simple treatments also have the following problems. Even the small amount of calcium ions contained in commonly used $\mathrm{NaOH}$ reagent enters into the sodium titanate formed on the Ti metal and its alloys by these treatments, suppressing surface apatite formation in SBF or the living body [70]. The sodium titanate formed on the Ti metal and its alloys by these simple treatments tends to lose its sodium ions during storage in a humid environment due to the exchange of the sodium ions with $\mathrm{H}_{3} \mathrm{O}^{+}$ions in the moisture, resulting in decreased surface apatite formation [71]. 
All these problems of the simple $\mathrm{NaOH}$ and heat treatments would be solved if the sodium titanate could be replaced with calcium titanate. Unfortunately, calcium titanate cannot be formed on Ti metal or its alloys by simple $\mathrm{Ca}(\mathrm{OH})_{2}$ solution and heat treatments, since the solubility of $\mathrm{Ca}(\mathrm{OH})_{2}$ in water is very low. If the Ti metal is soaked in $100 \mathrm{mM}$ of $\mathrm{CaCl}_{2}$ solution at $40{ }^{\circ} \mathrm{C}$ for $24 \mathrm{~h}$ after the $\mathrm{NaOH}$ treatment, the $\mathrm{Ca}^{2+}$ ions completely replace the $\mathrm{Na}^{+}$ions in the sodium hydrogen titanate formed by the $\mathrm{NaOH}$ treatment with calcium titanate and form by the subsequent heat treatment. This calcium titanate forms hardly any apatite on its surface in SBF, since it scarcely releases any calcium ions. However, if the Ti metal is subsequently exposed to hot water at $80{ }^{\circ} \mathrm{C}$ for $24 \mathrm{~h}$, the $\mathrm{Ca}^{2+}$ ions on the surface of the calcium titanate are partially replaced by the $\mathrm{H}_{3} \mathrm{O}^{+}$ions in the water to form a Ca-deficient calcium titanate on its surface, as shown in Fig. (14) [72]. Consequently, the rate of the $\mathrm{Ca}^{2+}$ ions release from the $\mathrm{Ti}$ metal is increased, increasing the apatite formation on the Ti metal. The apatite-forming ability conferred by these treatments is maintained even after storage in a humid environment for a long time [72].

These treatments are effective not only for pure Ti metal, but also for new kinds of Ti-based alloy such as Ti-15Zr4Nb-4Ta, Ti-29Nb-13Ta-4.6Zr and Ti-35Nb-2Ta-3Zr-0.3O alloys to induce apatite-forming ability in SBF, as shown in Fig. (15) [72-74]. The apatite-forming capacity conferred by these treatments is maintained even after storage in a humid environment for a long period [73].

Sawada et al. reported that when $10 \mathrm{mM} \mathrm{Ca}(\mathrm{OH})_{2}$ solution replaced the $100 \mathrm{mM} \mathrm{CaCl}$ solution during these treatments, the apatite formation of the Ti metal increased [75]. However, it should be noted that $\mathrm{Ti}$ metal that was chemically treated, but not subsequently heat-treated, had only a low level of scratch resistance [72].

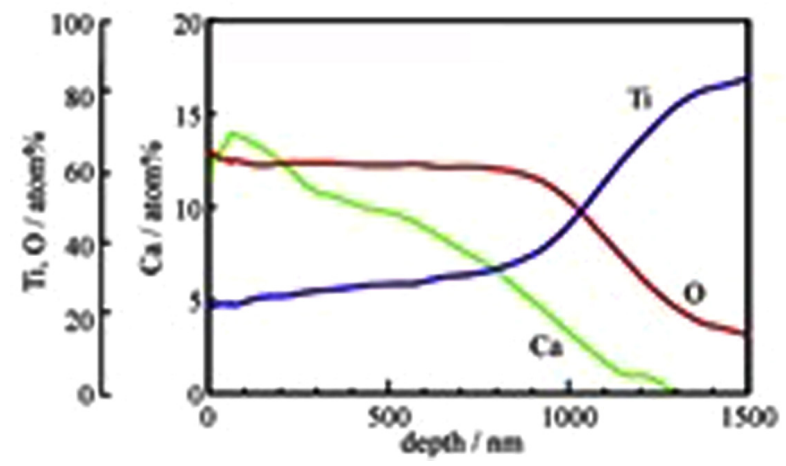

Fig. (14). Depth profile of Auger electron spectroscopy of Ti metal subjected to $\mathrm{NaOH}, \mathrm{CaCl}_{2}$, heat and water treatments. Reproduced from ref. [72].

Ti metal as well as its alloys with Ca-deficient calcium titanate formed on their surfaces by the $\mathrm{NaOH}, \mathrm{CaCl}_{2}$, heat, and water treatments were confirmed to tightly bound to the surrounding bone without any fibrous tissue intervening at the interface with the bone, as shown in Fig. (16) [76, 77], as expected from the surface apatite formation in SBF.

If the $\mathrm{NaOH}, \mathrm{CaCl}_{2}$, heat and water treatments are slightly modified, various kinds of functional ion such as $\mathrm{Mg}^{2+}, \mathrm{Sr}^{2+}$, or $\mathrm{Zn}^{2+}$ ions, which are known to promote bone growth, can be incorporated into the surface calcium titanate layer. When the Ti metal or its alloys were soaked in $\mathrm{CaCl}_{2}$ solution containing $\mathrm{Mg}^{2+}$ [78], $\mathrm{Sr}^{2+}$ [79], or $\mathrm{Zn}^{2+}$ [80] ions after the $\mathrm{NaOH}$ treatment, and then subjected to the heat
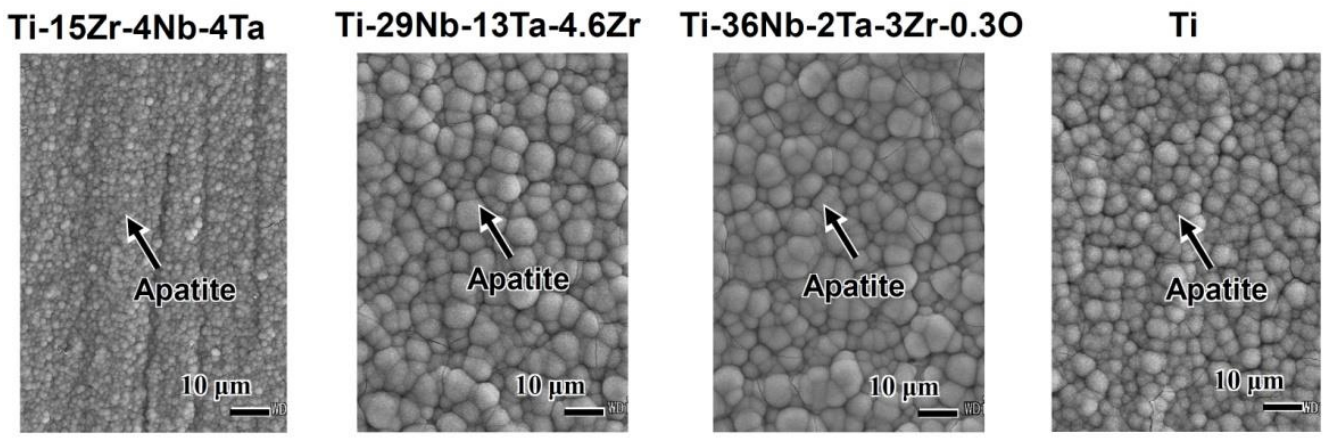

Fig. (15). SEM photographs of surfaces of Ti metal and Ti-Zr-Nb-Ta alloys subjected to $\mathrm{NaOH}, \mathrm{CaCl}_{2}$, heat, and water treatments, after soaking in SBF for 3 days. Reproduced from Ref. [73, 74].
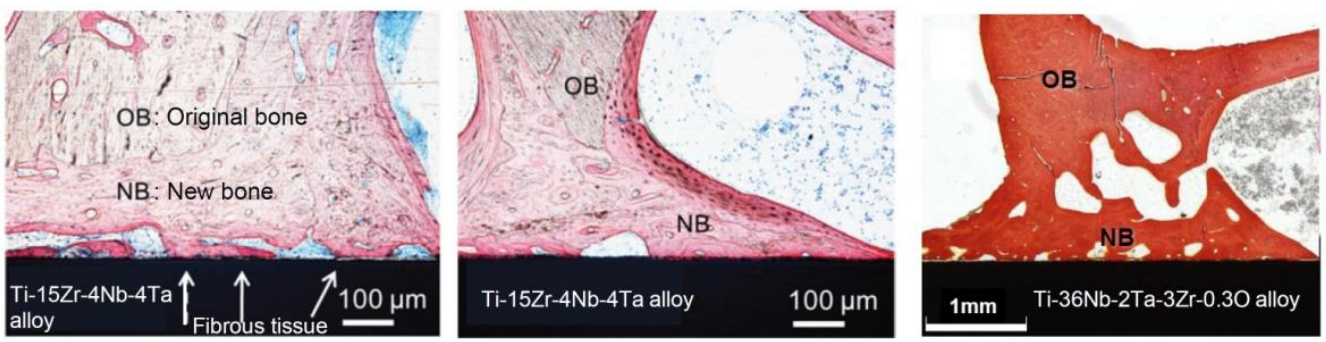

Fig. (16). Optical micrographs of Ti-Zr-Nb-Ta alloys subjected to $\mathrm{NaOH}, \mathrm{CaCl}_{2}$, heat and water treatments at their interfaces with the bone, 16 weeks after implantation into the tibia of a rabbit, in comparison with an untreated specimen (left hand specimen). Reproduced from Ref. $[76,77]$. 
treatment and a final hot water treatment, layers of calcium titanate incorporating these functional ions were formed on their surfaces. When aqueous solutions containing functional ions were used instead of pure water at the final stage, a larger amount of functional ions was incorporated into the surface calcium titanate layer, as shown in Fig. (17) [78]. The resultant products not only formed apatite on their surfaces in SBF, but also slowly released the functional ions into phosphate-buffered saline at $36.5{ }^{\circ} \mathrm{C}$, as shown in Fig. (18) [78-80]. These ions will be released from the Ti metal also to the living body to promote growth of the surrounding bone. Consequently, an early bonding of the Ti metal with the surrounding bone will take place.

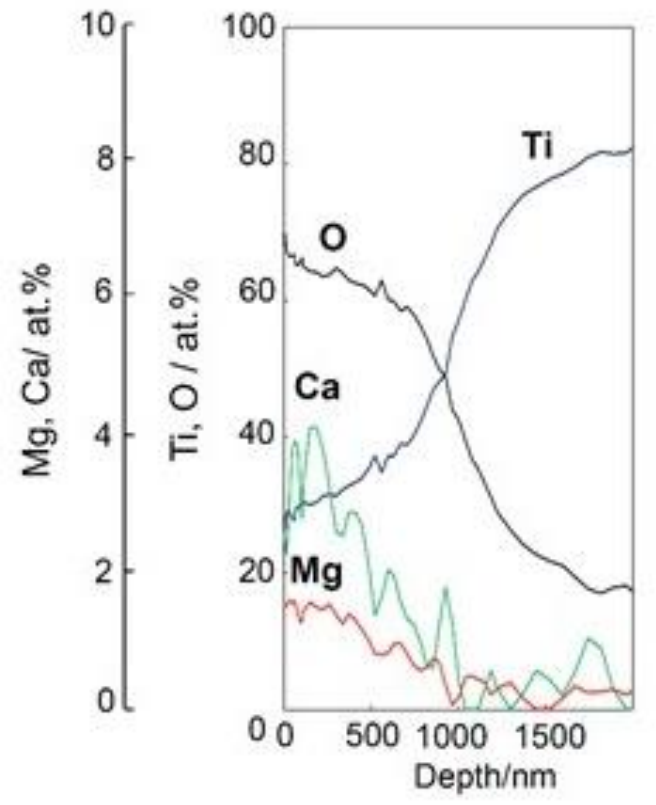

Fig. (17). Depth profile of XPS of Ti metal subjected to $\mathrm{NaOH}$, $\mathrm{CaCl}_{2} / \mathrm{MgCl}_{2}$, heat, and $\mathrm{MgCl}_{2}$ treatments. Reproduced from Ref. [78].

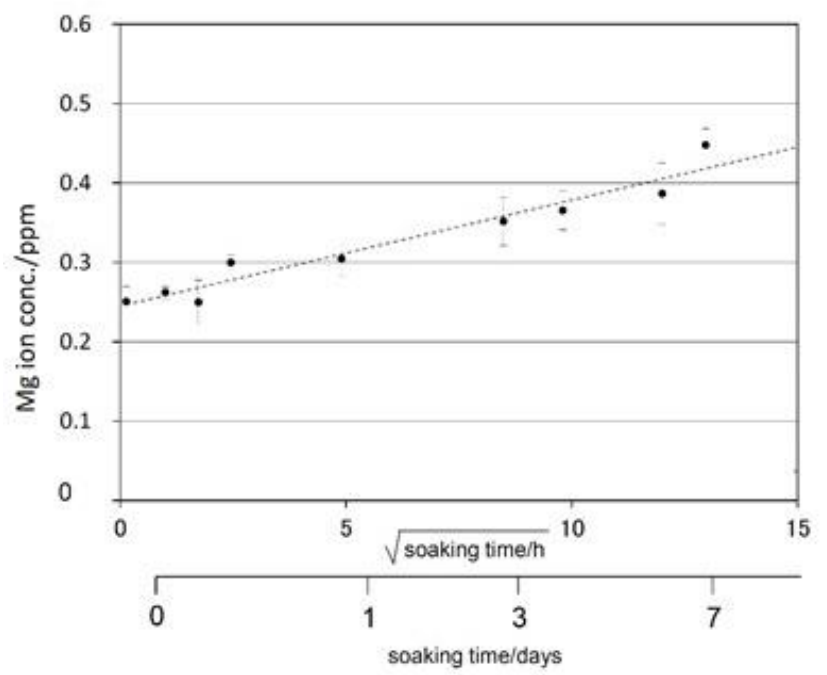

Fig. (18). $\mathrm{Mg}$ ion release from $\mathrm{Ti}$ metal subjected to $\mathrm{NaOH}$, $\mathrm{CaCl}_{2} / \mathrm{MgCl}_{2}$, heat, and $\mathrm{MgCl}_{2}$ treatments into phosphate-buffered saline at $36.5{ }^{\circ} \mathrm{C}$. Reproduced from Ref. [78].
When Ti metal or its alloys were soaked in $\mathrm{AgNO}_{3}$ solution instead of pure water at the final stage of the $\mathrm{NaOH}$, $\mathrm{CaCl}_{2}$, heat, and water treatments, an $\mathrm{Ag}$-containing calcium titanate layer was formed on the Ti metal surface, as shown in Fig. (19) [81]. The resultant product not only formed apatite on its surface in SBF, but also slowly released the $\mathrm{Ag}^{+}$ions into the fetal bovine serum that exhibited antibacterial activity. The $\mathrm{Ag}^{+}$ions are expected to be released from the $\mathrm{Ti}$ metal in the living body to prevent infection.

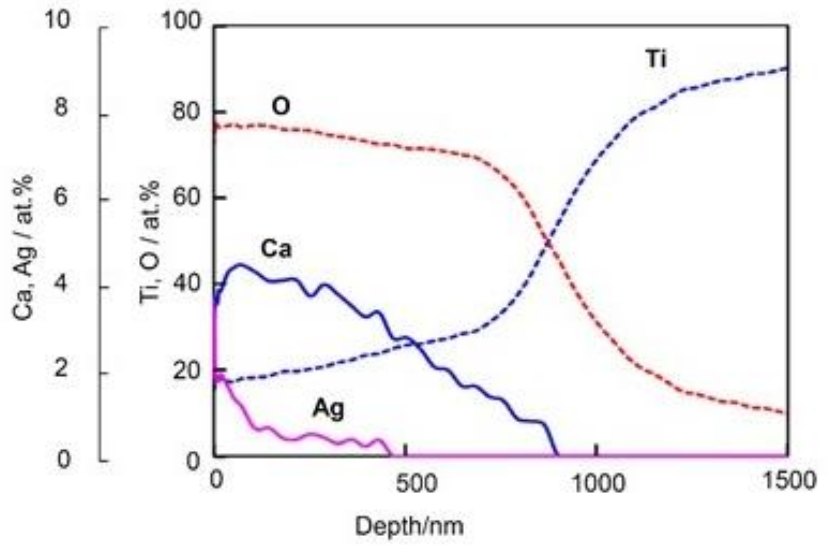

Fig. (19). Depth profile of Auger electron spectroscopy of Ti metal subjected to $\mathrm{NaOH}, \mathrm{CaCl}_{2}$, heat, and $\mathrm{AgNO}_{3}$ treatments. Reproduced from Ref. [81].

\section{CHEMICAL AND HEAT TREATMENTS FOR INDUCING APATIITE FORMATION ON METALS OTHER THAN Ti METAL}

A zirconia gel prepared by a sol-gel method also formed apatite on its surface in SBF within 3 days, when heattreated at 600 or $800{ }^{\circ} \mathrm{C}$ [82]. This indicates that zirconium metal is able to form apatite in SBF when its surface is chemically slightly modified. However, a zirconium metal plate formed apatite only scarcely on its surface in SBF even after 28 days, when it was treated with 5-15 M NaOH solution at $95{ }^{\circ} \mathrm{C}$ for $24 \mathrm{~h}$ [83]. Chen et al. [84] reported that a zirconium metal plate produced by sintering of metal powders formed apatite on its surface in SBF within 7 days, when soaked in $10 \mathrm{M} \mathrm{NaOH}$ solution at $60{ }^{\circ} \mathrm{C}$ for $24 \mathrm{~h}$ and then heat-treated at $600{ }^{\circ} \mathrm{C}$ for $1 \mathrm{~h}$ in vacuum.

A niobium oxide gel prepared by a sol-gel method also formed apatite on its surface in SBF within 7 days [85]. However, niobium metal did not form apatite on its surface within 14 days when treated with $0.5-2.0 \mathrm{M} \mathrm{NaOH}$ solution at $60{ }^{\circ} \mathrm{C}$ for $24 \mathrm{~h}$ [85]. Treatment by $\mathrm{NaOH}$ solution with concentrations higher than $2 \mathrm{M}$ produced cracks at the metal surface. Wang et al. [86] reported that niobium metal forms apatite on its surface in SBF within 7 days when soaked in $0.5 \mathrm{M} \mathrm{NaOH}$ solution at $80{ }^{\circ} \mathrm{C}$ for $24 \mathrm{~h}$, and then heat-treated at $600{ }^{\circ} \mathrm{C}$ for $1 \mathrm{~h}$ in vacuum.

A tantalum oxide gel prepared by a sol-gel method also formed apatite on its surface in SBF within 7 days [87]. Tantalum metal formed apatite on its surface in SBF without 
any surface chemical modification [88]. However, whereas it required an induction period as long as 4 weeks for apatite to form, apatite was formed on a sodium tantalate hydrogel surface layer within 7 days when treated with $0.2-0.5 \mathrm{M}$ $\mathrm{NaOH}$ solution at $60{ }^{\circ} \mathrm{C}$ for $24 \mathrm{~h}$, and subsequently heattreated at $300{ }^{\circ} \mathrm{C}$ for $1 \mathrm{~h}$. The bonding strength of the surface layer to the substrate increased without any decrease in its apatite-forming ability $[89,90]$. The reason why the $\mathrm{NaOH}$ treatment enhanced the apatite-forming ability was interpreted in terms of apatite nucleation induced by $\mathrm{Ta}-\mathrm{OH}$ groups formed on the Ta metal in SBF [91]. The tantalum metal subjected to the $0.5 \mathrm{M} \mathrm{NaOH}$ treatment and $300^{\circ} \mathrm{C}$ heat treatment was confirmed to be strongly bonded to the living bone without intervention of the fibrous tissue at the interface to the bone within 16 weeks by animal experiments using a rabbit model [92].

However, in contrast to the results above, an alumina gel prepared by a sol-gel method did not form apatite on its surface in SBF [3], this indicates that Al metal femoral condyle on its surface even if its surface was chemically modified.

\section{CLINICAL APPLICATIONS OF BIOACTIVE Ti PREPARED BY SIMPLE CHEMICAL AND HEAT TREATMENTS}

The simple $\mathrm{NaOH}$ and heat treatments were applied to a porous Ti metal layer on the acetabular shell and femoral stem of a total artificial hip joint made of Ti-6Al-2Nb-Ta alloy. The resultant bioactive hip joint has been clinically used in more than 10,000 patients since 2007 in Japan [93, 94], as shown in Fig. (20). It was confirmed by two implants that were retrieved 2 weeks and 8 years after implantation, respectively, due to femoral fracture and infection that the implant surface became intimately integrated with newly grown bone as early as 2 weeks after implantation and had maintained this integrity for 8 years [94].

A porous $\mathrm{Ti}$ metal subjected to the $\mathrm{NaOH}, \mathrm{HCl}$ and heat treatments was successfully applied to a spinal fusion device in a canine model [95]. Based on this result, it was subjected to clinical trials as a spinal fusion device for five human patients between November 2008 and June 2009, as shown in Fig. (21) [96]. All these cases had a successful outcome.

It is believed that $\mathrm{Ti}$ metal and its alloys that had bioactivity conferred upon them by these simple chemical and heat treatments are useful for a variety of bone-repairing devices used under load-bearing conditions in both the orthopedic and dental fields.

\section{CONCLUSION}

1. When Ti metal is heat-treated after exposure to $\mathrm{HCl}$ or $\mathrm{NaOH}$ solutions with different $\mathrm{pHs}$, it forms apatite on its surface in a simulated body fluid when exposed to a strongly acidic or alkaline solution.

2. This is because it forms a highly positively charged titanium oxide or highly negatively charged sodium titanate on its surface.

3. These Ti metals tightly bond to living rabbit tibial bone.
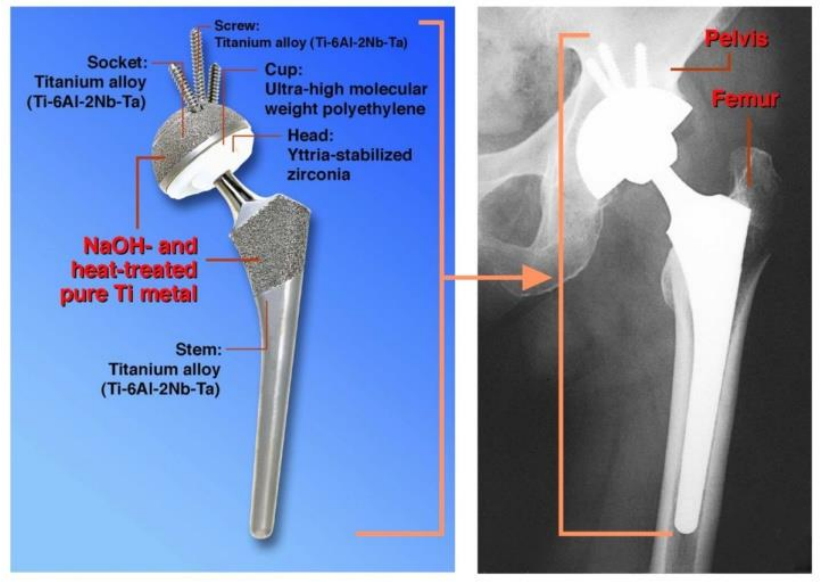

Fig. (20). Artificial hip joint, porous Ti metal layer of which was heat-treated after exposure to $\mathrm{NaOH}$ solution, after Refs. [93, 94].
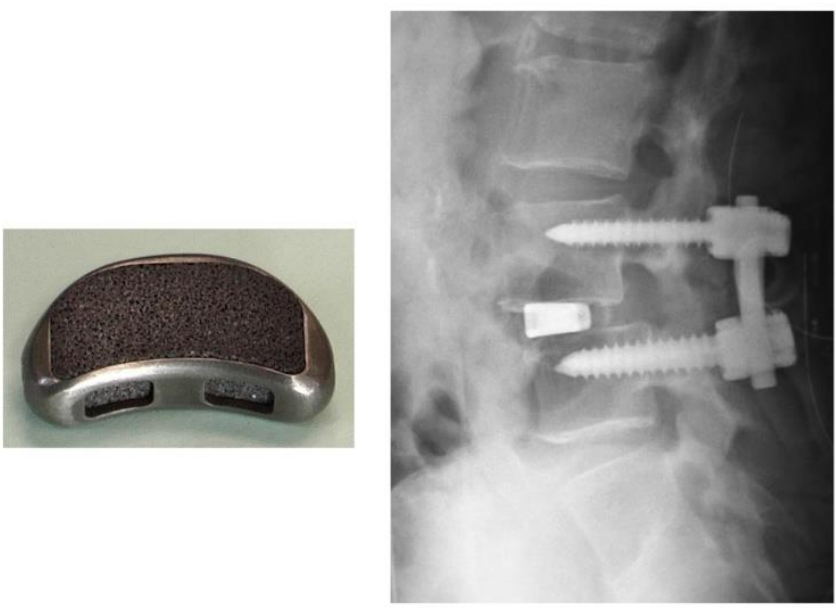

Fig. (21). Spinal fusion device of porous Ti metal subjected to $\mathrm{NaOH}, \mathrm{HCl}$ and heat treatments, and its clinical application. Reproduced from Ref. [96].

4. The general principle for obtaining bone-bonding $\mathrm{Ti}$ metal by chemical and heat treatments is clear from these results.

5. Porous Ti metal heat-treated after acid treatment exhibits not only osteoconductivity but also osteoinductivity. However, Ti metal heat-treated after alkaline treatment exhibits only osteoconductivity, since the sodium ions are being released from the sodium titanate into the narrow space of the pores thus hindering osteoinductivity.

6. For some kinds of Ti-based alloys, the acid and heat treatments are ineffective to induce apatite formation, since oxides of the alloying elements are formed at their surfaces after the heat treatment.

7. However, even those alloys exhibit apatite formation when subjected to acid and heat treatments after a $\mathrm{NaOH}$ treatment, since the alloying elements are removed from the surface by latter.

8. These acid and heat treatments after $\mathrm{NaOH}$ treatment are also effective even for the pure Ti metal. Porous Ti metal 
subjected to these treatments exhibits not only osteoconductivity, but also osteoinductivity.

9. The $\mathrm{NaOH}$ and heat treatment is not effective for certain kinds of Ti-based alloy, since the alloying elements suppress the release of sodium ions.

10. However, even those alloys exhibit apatite formation when subjected to $\mathrm{CaCl}_{2}$ after $\mathrm{NaOH}$ treatments, since Ca-deficient calcium titanate is being formed on their surfaces after subsequent heat and hot water treatments.

11. Various kinds of functional ion that promote bone growth, confer antibacterial activity etc., can be incorporated into the surface calcium titanate layer by modified $\mathrm{NaOH}, \mathrm{CaCl}_{2}$, heat, and water treatments.

12. The bioactive $\mathrm{Ti}$ metal subjected to the $\mathrm{NaOH}$ and heat treatment has been successfully used as a part of an artificial hip joint since 2007 in Japan.

13. A porous $\mathrm{Ti}$ metal subjected to $\mathrm{NaOH}, \mathrm{HCl}$ and heat treatment has undergone successful clinical trials as a spinal fusion device.

\section{CONFLICT OF INTEREST}

The authors confirm that this article content have no conflict of interest.

\section{ACKNOWLEDGEMENTS}

All animal and clinical experiments presented in this paper were performed by Professor Takashi Nakamura and his coworkers at the Department of Orthopedic Surgery, Kyoto University, Japan.

\section{REFERENCES}

[1] T. Kokubo, Ed., Bioceramics and their Clinical Applications. Cambridge: Woodhead Pub., 2008.

[2] T. Kokubo, and H. Takadama, "How useful is SBF in predicting in vivo bone bioactivity?", Biomaterials, vol. 15, pp. 2907-2915, May 2006.

[3] P. Li, C. Ohtsuki, T. Kokubo, K. Nakanishi, N. Soga, and K. de Groot, "The role of hydrated silica, titania, and alumina in inducing apatite on implants" J. Biomed. Mater. Res. vol. 28, pp. 7-15, January 1994.

[4] D. A. Armitage, R. Mihoc, T. J. Tate, D. S. McPhail, R. Chater, J. A. Hobkirk, L. Shinawi, and F. H. Jones, "The oxidation of calcium implanted titanium in water: a depth profiling study", Appl. Surf. Sci., vol. 253, pp. 4085-4093, February 2007.

[5] S. N. Nayab, F. H. Jones, and I. Olsen, "Effects of calcium ionimplantation of titanium on bone cell function in vitro", J. Biomed. Mater. Res., vol. 83A, pp. 296-302, November 2007.

[6] T. R. Rautray, R. Narayanan, T. -Y. Kwon, and K. -H. Kim, "Surface modification of titanium and titanium alloys by ion implantation", J. Biomed. Mater. Res. Part B: Appl. Biomater., vol. 93B, pp. 581-591, May 2010.

[7] W. Dong, T. Zhang, J. Epstein, L. Cooney, H. Wang, Y. Li, Y-B. Jiang, A. Cogbill, V. Varadan, and Z. R. Tian, "Multifunctional Nanowire Bioscaffolds on Titanium", Chem. Mater., vol. 19, pp. 4454-4459, August 2007.

[8] J. -W. Park, K. B. Park, and J. -Y. Suh, "Effects of calcium ion incorporation on bone healing of Ti6Al4V alloy implants in rabbit tibia”, Biomaterials, vol. 28, pp. 3306-3313, August 2007.
[9] M. Ueda, M. Ikeda, and M. Ogawa, "Chemical-hydrothermal combined surface modification of titanium for improvement of osteointegration", Mater. Sci. Eng. C, vol.29, pp. 994-1000, April 2009.

[10] X. -B. Chen, Y. C. Li, J. D. Plessis, P. D. Hodgson, and C. Wen, "Influence of calcium ion deposition on apatite-inducing ability of porous titanium for biomedical applications", Acta Biomater., vol. 5, pp. 1808-1020, June 2009.

[11] L. Zhang, Y. Ayukawa, R.Z. LeGeros, S. Matsuya, K. Koyano, and $\mathrm{K}$. Ishikawa, "Tissue-response to calcium-bonded titanium surface", J. Biomed. Mater. Res. part A, vol. 95A, pp. 33-39, October 2010.

[12] J. -W. Park, Y. -J. Kim, J. -H. Jang, T.G. Kwon, Y. -C. Bae, and J. -Y. Suh, "Effects of phosphoric acid treatment of titanium surface on surface properties, osteoblast response and removal of torque forces", Acta Biomater., vol. 6, pp. 1661-1670, April 2010.

[13] Y. -T. Suh, "The significance of the surface properties of oxidized titanium to the bone response: special emphasis on potential biochemical bonding of oxidized titanium implant", Biomaterials, vol. 24, pp. 3893-3907, October 2003.

[14] Y. Shibata, D. Suzuki, S. Omori, R. Tanaka, A. Murakami, Y. Ktaoka, K. Baba, R. Kamijo, and T. Miyazaki, “ The characteristics of in vitro biological activity of titanium surfaces anodically oxidized in chloride solution", Biomaterials, vol. 31, pp. 85468555 , November 2010.

[15] L. M. Bjursten, L. Rasmusson, S. Oh, G. C. Smith, K. S. Brammer, and $\mathrm{S}$. Jin, "Titanium dioxide nanotubes enhance bone bonding in vivo", J. Biomed. Mater. Res., vol. 92A, pp. 1218-1224, March 2010.

[16] L. Zhao, S. Mei, P. K. Chu, Y. Zhang, and Z. Wu, "The influence of hierarchical hybrid micro/nano-textured titanium surface with titania nanotubes on osteoblast functions", Biomaterials, vol. 31, pp. 5072-5082, July 2010.

[17] S. Minagar, J. Wang, C. C. Barndt, E. P. Ivanova, and C. Wen, "Cell response of anodized nanotubes on titanium and titanium alloys", J. Biomed. Mater. Res. Part A, vol. 101A, pp. 2726-2739, September 2013

[18] P. Whiteside, E. Matykina, J. E. Gough, P. Skeldon, and G. E. Thompson, "In vitro evaluation of cell proliferation and collagen synthesis on titanium following plasma electrolytic oxidation", $J$. Biomed. Mater. Res. Part A, vol.94A, pp. 38-46, July 2010.

[19] M. Diefenback, T. Muckley, C. Shrader, J. Schmidt, S. Zankovych, J. Bossert, K. D. Jandt, M. Faucon, and U. Finger, "The effect of plasma chemical oxidation of titanium alloy on bone-implant contact in rats", Biomaterials, vol. 32, pp. 8041-8047, November 2011.

[20] L. Xie, X. Liao, G. Yin, Z. Huang, D. Yan, Y. Yao, W. Liu, X. Chen, and J. Gu, "Preparation, characterization, in vitro bioactivity, and osteoblast adhesion of multi-level porous titania layer on titanium by two-step anodization treatment", J. Biomed. Mater. Res. Part A, vol. 98A, pp. 312-320, August 2011.

[21] P. Zhang, Z. Zhang, W. Li, and M. Zhu, "Effect of Ti-OH groups on microstructure and bioactivity of $\mathrm{TiO}_{2}$ coating prepared by micro-ark oxidation“ Appl. Surf. Sic., vol. 268, pp. 381-386, March 2013.

[22] R. Zhou, D. Wei, H. Yang, S. Cheng, W. Feng, B. Li, Y. Wang, D. Jia, and Y. Zhou, "Osseointegration of bioactive microarc oxidized amorphous phase/ $\mathrm{TiO}_{2}$ nanocrystals composite coatings on titanium after implantation into rabbit tibia", Mater. Sci.; Mater. Med., vol. 25, pp. 1307-1318, May 2014.

[23] W. Zhou, X. Zhou, X. Wu, L. Yuan, Q. Shu, Y. Xia, and K. Ostrikov, "Plasma-controlled nanocrystallinity and phase composition of $\mathrm{TiO}_{2}$ : a smart way to enhance biomimetic response", J. Biomed. Mater. Res. Part A, vol. 81A, pp. 453-464, May 2007. 
[24] A. Sugino, C. Ohtsuki, K. Tsuru, S. Hayakawa, T. Nakano, Y. Okazaki, and A. Osaka, "Effect of spatial design and thermal oxidation on apatite formation on Ti-15Zr-4Ta-4Nb alloy" Acta Biomater., vol. 5, pp. 298-304. January 2009.

[25] X. Zhao, X. Liu, J. You, Z. Chen, and C. Ding," Bioactivity and cytocompatibility of plasma-sprayed titania coating treated by sulfuric acid treatment", Surf. Coat. Tech., vol. 202, pp. 3221-3226, April 2008.

[26] X. Liu, Z. Zhao, and Y. Leng. "Biomimetic calcium phosphate coatings on nitric-acid-treated titanium surfaces", Mater. Sci. Eng. C, vol. 27, pp. 700-708, May 2007.

[27] U. Turkan, and M. Guden, "The effect of nitiric acid surface treatment on $\mathrm{CaP}$ deposition on Ti6Al4V open-cell foams in SBF solution”, Surf. Coat. Tech., vol. 205, pp. 1904-1916, December 2010.

[28] L. F. Cooper, Y. Zhou, J. Takebe, J. Guo, A. Abron, A. Holmen, and J. E. Ellingsen, "Fluoride modification effects on osteoblast behavior and bone formation at $\mathrm{T}_{\mathrm{i}} \mathrm{O}_{2}$ grit-blasted c.p. titanium endosseous implants", Biomaterials, vol. 27, pp. 926-936, February 2006.

[29] Y. Li, S. Zou, D. Wang, G. Feng, C. Bao, and J. Hu, "The effect of hydrofluoric acid treatment on titanium implant osseointegration in ovariecomized rats", Biomaterials, vol. 31, pp. 3266-3273, April 2010.

[30] K. Takeuchi, L. Saruwatari, H. Nakamura, J-M. Yang, and T. Ogawa, "Enhanced intrinsic biomechanical properties of osteoblastic mineralized tissue on roughened titanium surface" $J$. Biomed. Mater. Res. Part A, vol. 72A, pp. 296-305, March 2005.

[31] X. Zhao, X. Liu, and C. Ding, "Acid-induced bioactive titania surface", J. Biomed. Mater. Res. Part A, vol. 75A, pp. 888-894, December 2005.

[32] J. -M. Wu, S. Hayakawa, K. Tsuru, and A. Osaka, "Lowtemperature preparation of anatase and rutile layers on titanium substrates and their ability to induce vitro apatite deposition", $J$. Am. Ceram Soc., vol. 87, pp. 1635-1642, September 2004.

[33] M. Karthega, and N. Rajendran, "Hydrogen peroxide treatment on Ti-6Al-4V alloy: a promising surface modification technique for orthopaedic application" Appl. Surf. Sci., vol. 256, pp. 2176-2183, January 2010.

[34] S. Ferraris, S. Spriano, G. Pan, A. Venturello, C. L. Bianchi, R. Chiesa, M. G. Faga, G. Maina, and E. Verne, "Surface modification of T-6Al-4V alloy for biomineralization and specific biological response: part 1, inorganic modification", J. Mater. Sci.: Mater. Med., vol. 22, pp. 533-545, March 2011.

[35] X. -X Wang, S. Hayakawa, K. Tsuru, and A. Osaka, "Bioactive titania gel layers formed by chemical treatment of Ti substrate with $\mathrm{H}_{2} \mathrm{O}_{2} / \mathrm{HCl}$ solution", Biomaterials, vol. 23, pp. 1353-1357, March 2002.

[36] M. -H. Lee, H. -S. Park, K. -S. Min, S. -G. Ahn, J. -M.Park, K. -Y. Song, and C. -W. Park, "Evaluation of in vitro tests for surfacemodified titanium by $\mathrm{H}_{2} \mathrm{SO}_{4}$ and $\mathrm{H}_{2} \mathrm{O}_{2}$ treatment", Met. Mater. Int., vol. 13, No. 2, pp. 109-115, April 2007.

[37] D.K. Pattanayak, S. Yamaguchi, T. Matsushita, T. Nakamura, and T. Kokubo, "Apatite-forming ability of titanium in terms of $\mathrm{pH}$ of the exposed solution", J. R. Soc. Interface, vol. 9, pp. 2145-2155, September 2012.

[38] T. Kokubo, D.K. Pattanayak, S. Yamaguchi, H. Takadama, T. Matushita T. Kawai, M. Takemoto, S. Fujibayashi, and Takashi Nakamura, "Positively charged bioactive charged bioactive $\mathrm{Ti}$ metal prepared by simple chemical and heat treatments", J. R. Soc. Interface, vol. 7, pp. S503-S513, October 2010.

[39] H. -M. Kim, T. Himeno, M. Kawashita, J. -H. Lee, T. Kokubo, and T. Nakamura, "Surface potential change in bioactive titanium metal during the process of apatite formation in simulated body fluid", $J$. Biomed. Mater. Res. Part A, vol. 67A, pp. 1305-1309, December 2003.
H. Takadama, H.-M. Kim, T. Kokubo, and T. Nakamura, ”An Xray photoelectron spectroscopy study of the process of apatite formation on bioactive titanium metal", J. Biomed. Mater. Res., vol. 55, pp. 185-193, May 2001.

[41] H. Takadama, H.-M. Kim, T. Kokubo, and T. Nakamura, "TEMEDX study of mechanism of bonelike apatite formation on bioactive titanium metal in simulated body fluid", J. Biomed. Mater. Res., vol. 57, pp. 441-448, December 2001.

[42] E. Conforto, and D. Caillard, "A fast method for determining favourable orientation relationships and interface plates: Application to titanium-titanium hydrides transformations", Acta Mater., vol. 55. pp. 785-798, February 2007.

[43] J. M. Gold, M. Schmidt, and S. G. Steinmann, "XPS study of amino acid adsorption to titanium surfaces", Helv. Phys. Acta, vol. 62, pp.246-249, 1989,

[44] S. Yamaguchi, H. Takadama, T. Matsushita, T. Nakamura, and T. Kokubo, "Cross-sectional analysis of the surface ceramic layer developed on $\mathrm{Ti}$ metal by $\mathrm{NaOH}$-heat treatment and soaking in SBF", J. Ceram. Soc. Japan, vol. 117, pp.1126-1130, October 2009.

[45] T. Kawai, M. Takemoto, S. Fujibayashi, M. Neo, H. Akliyama, S. Yamaguchi, D. K. Pattanayak, T. Matsushita, T. Nakamura, and T. Kokubo, "Bone-bonding properties of Ti metal subjected to acid and heat treatments", J. Mater. Sci.: Mater. Med., vol. 23, pp. 2981-2992, December 2012.

[46] P. G. Coelho, J. M. Granjeiro, G. E. Romanos, M. Suzuki, N. R .F. Silva, G. Cardaropoli, V. P. Thompson, and J. E. Lemons, "Basic research methods and current trends of dental implant surfaces", $J$. Biomed. Mater. Res. Part B: Appl. Biomater., vol. 88B, pp. 579596, February 2009.

[47] T. Kawai, M. Takemoto, S. Fujibayashi, H. Akiyama, S. Yamaguchi, D. K. Pattanayak, K. Doi, T. Matsushita, T. Nakamura, T. Kokubo, and S. Matsuda, "Osteoconduction of porous Ti metal enhanced by acid and heat treatments", J. Mater. Sci.: Mater. Med., vol. 24, pp. 1701-1715, July 2013.

[48] T. Kawai, M. Takemoto, S. Fujibayashi, H. Akiyama, M. Tanaka, S. Yamaguchi, D. K. Pattanayak, K. Doi, T. Matsushita, T. Nakamura, T. Kokubo, and S. Matsuda, "Osteoinduction on acid and heat treated porous Ti metal samples in canine muscle", PLoS ONE, vol. 9, no. 2, p. e88366, February 2014.

[49] W. -Q. Yan, T. Nakamura, M. Kobayashi, H. -M. Kim, F. Miyaji, and T. Kokubo, "Bonding of chemically treated titanium implants to bone", J. Biomed. Mater. Res., vol. 37, pp. 267-275, November 1997.

[50] S. Nishiguchi, S. Fujibayashi, H. -M. Kim, T. Kokubo, and T. Nakamura, "Biology of alkali-and heat-treated titanium implants", J. Biomed. Mater. Res., vol. 67A, pp. 26-35, October 2003.

[51] S. Nishiguchi, H. Kato, M. Neo, M. Oka, H. -M. Kim, T. Kokubo, and T. Nakamura, "Alkali-and heat-treated porous titanium for orthopedic implants”, J. Biomed. Mater. Res., Vol. 54, pp 198-208, February 2001.

[52] M. Takemoto, S. Fujibayashi, M. Neo, J. Suzuki, T. Matsushita, T. Kokubo, and T. Nakamura, "Osteoinductive porous titanium implants: Effect of sodium removal by dilute $\mathrm{HCl}$ treatment", Biomaterials, vol. 27, pp. 2682-2691, May 2006.

[53] M. Tsukanaka, K. Yamamoto, S. Fujibayashi, D. K. Pattanayak, T. Matsushita, T. Kokubo, S. Matsuda, and H. Akiyama, "Evaluation of bioactivity of alkali-and heat-treated titanium using fluoresent mouse osteoblasts", J. Bone. Miner. Metab., December 2013. [Online] Available: http://dx.doi.org/10.1007/s00774-013-0544-8. [Accessed May 30, 2014].

[54] S. Yamaguchi, H. Takadama, T. Matsushita, T. Nakamura, and T. Kokubo, "Preparation of bioactive Ti-15Zr-4Nb-4Ta alloy from $\mathrm{HCl}$ and heat treatments after an $\mathrm{NaOH}$ treatment", J. Biomed. Mater. Res. PartA, vol. 97A, pp. 135-144, May 2011. 
[55] D.K. Pattanayak, T. Kawai, T. Matsusita, H. Takadama, T. Nakamura, and T. Kokubo, "Effect of $\mathrm{HCl}$ concentrations on apatite-forming ability of $\mathrm{NaOH}-\mathrm{HCl}$-and heat-treated titanium metal", J. Mater. Sci.: Mater. Med., vol. 20, pp.2401-2411, December 2009.

[56] D. K. Pattanayak, S. Yamaguchi, T. Matsushita, and T. Kokubo, "Effect of heat treatments on apatite-forming ability of $\mathrm{NaOH}$-and HCl-treated titanium metal", J. Mater. Sci.: Mater. Med., vol. 22, pp. 273-278, February 2011.

[57] D. K. Pattanayak, S. Yamaguchi, T. Matsushita, and T. Kokubo, "Nanostructured positively charged bioactive $\mathrm{TiO}_{2}$ layer formed on Ti metal by $\mathrm{NaOH}$, acid and heat treatments", J. Mater. Sci.: Mater. Med., vol. 22, pp. 1803-1812, August 2011.

[58] S. Fujibayashi, M. Neo, H-M. Kim, T. Kokubo, and T. Nakamura, "Osteoinduction of porous bioactive titanium metal", Biomaterials, vol. 25, pp. 443-450, February 2004.

[59] A. Fukuda, M. Takemoto, T. Saito, S. Fujibayashi, M. Neo, D. K. Pattanayak, T. Matsushita, K. Sasaki, N. Nishida, T. Kokubo, and T. Nakamura, "Osteoinduction of porous $\mathrm{Ti}$ implants with a channel structure fabricated by selective laser melting", Acta Biomater, vol. 7, pp. 2327-2336, May 2011

[60] M. Takemoto, S. Fujibayashi, M. Neo, J. Suzuki, T. Kokubo, and T. Nakamura, "Mechanical properties and osteoconductivity of porous bioactive titanium", Biomaterials, vol. 26, pp. 6014-6023, October 2005

[61] K. Tanaka, M. Takemoto, S. Fujibayashi, K. Kawanabe, T. Matsushita, T. Kokubo and T. Nakamura, "Long term study of osteoconductivity of bioactive porous titanium metals: Effects of sodium removal by dilute $\mathrm{HCl}$ treatment", Key Eng. Mater. vol. 396-398, pp.353-356, October 2009.

[62] C. Zhao, X. Zhu, K. Liang, J. Ding, Z. Xiang, H. Fan, and X. Zhang, "Osteoinduction of porous titanium: a comparative study between acid-alkali and chemical-thermal treatments", J. Biomed. Mater. Res. Part B: Appl. Biomater., vol. 95B, pp. 387-396, November 2010

[63] D. K. Pattanayak, T. Matsushita, K. Doi, H. Takadama, T. Nakamura, and T. Kokubo, "Effect of oxygen content of porous titanium metal on its apatite-forming ability and compressive strength", Mater .Sci. Eng. C., vol. 29, pp. 1974-1978, August 2009.

[64] D. K. Pattanayak, A. Fukuda, T. Matsushita, M. Takemoto, S Fujibayashi, K. Sasaki, N. Nishida. T. Nakamura, and T. Kokubo, "Bioactive $\mathrm{Ti}$ metal analogous to human cancellous bone: Fabrication by selective laser melting and chemical treatments", Acta Biomater., vol. 7 pp. 1398-1406, March 2011.

[65] C. Aparicio, J. M. Manero, F. Conde, M. Pegueroles, J.A. Planell, M. Vallet-Regi, and F. J. Gil, "Acceleration of apatite nucleation on microrough bioactive titanium for bone-replacing implants", $J$. Biomed. Mater. Res. Part A, vol. 82A, pp. 521-529, September 2007.

[66] C. Aparicio, A. Padros, and F.-J. Gil, "In vivo evaluation of microrough and bioactive titanium dental implants using histometry and pull out tests", J. Mech. Behav. Biomed. Mater., vol. 4. pp. 16721682, November 2011.

[67] H. -M. Kim, F. Miyaji, T. Kokubo, and T. Nakamura, "Preparation of bioactive $\mathrm{Ti}$ and its alloys via simple chemical surface treatment", J. Biomed. Mater. Res., vol. 32, pp. 409-417, November 1996

[68] T. Ueno, N. Tsukimura, M. Yamada, and T. Ogawa, "Enhanced bone-integration capability of alkali-and heat-treated nanopolymorphic titanium in micro-to-nanoscale hierarchy", Biomaterials, vol. 32, pp. 7297-7308, October 2011.

[69] S. Nishiguchi, H. Kato, H. Fujita, H-M. Kim, F. Miyaji, T. Kokubo, and T. Nakamura, "Enhancement of bone-bonding strengths of titanium alloy implants by alkali and heat treatments",
J. Biomed. Mater. Res. (Appl. Biomater.), vol. 48, pp. 689-696, September 1999.

[70] T. Kizuki, H. Takadama, T. Matsushita, T. Nakamura, and T. Kokubo, "Effect of Ca contamination on apatite formation in a $\mathrm{Ti}$ metal subjected to $\mathrm{NaOH}$ and heat treatments", J. Mater. Sci. Mater. Med., vol. 24, pp. 635-644, March 2013.

[71] T. Kawai, T. Kizuki, H. Takadama, T. Matsushita, H. Unuma, T. Nakamura, and T. Kokubo, "Apatite formation on surface titanate layer with different Na content on Ti metal", J. Ceram. Soc. Jpn, vol. 118, pp. 19-24, January 2010.

[72] T. Kizuki, H. Takadama, T. Matsushita, T. Nakamura, and T. Kokubo, "Preparation of bioactive Ti metal surface enriched with calcium ions by chemical treatment", Acta Biomater., vol. 6, pp. 2836-2842, July 2010 .

[73] S. Yamaguchi, H. Takadama, T. Matsushita, T. Nakamura, and T. Kokubo, "Apatite-forming ability of Ti-15Zr-4Nb-4Ta alloy induced by calcium solution treatment", J. Mater. Sci.: Mater. Med., vol. 21, pp. 439-444, February 2010.

[74] S. Yamaguchi, T. Kizuki, H. Takadama, T. Matsushita, T. Nakamura, and T. Kokubo, "Formation of a bioactive calcium titanate layer on gum metal by chemical treatment", J. Mater. Sci.: Mater. Med., vol. 23, pp. 873-883, April 2012.

[75] R. Sawada, K. Kono, K. Isama, Y. Haishima, and A. Matsuoka, "Calcium-incorporated titanium surfaces influence the osteogenic differentiation of human mesenchymal stem cells", J. Biomed. Mater. Res. Part A, vol. 101A, pp. 2573-2585, September 2013

[76] A. Fukuda, M. Takemoto, T.Saito, S. Fujibayashi, M. Neo, S Yamaguchi, T. Kizuki, T. Matsushita, M. Niinomi, T. Kokubo, and T. Nakamura, "Bone bonding bioactivity of Ti metal and Ti-Zr-Nb$\mathrm{Ta}$ alloys with $\mathrm{Ca}$ ions incorporated on their surfaces by simple chemical and heat treatments", Acta Biomater., vol. 7, pp.13791386, March 2011

[77] M. Tanaka, M. Takemoto, S. Fujibayashi, T. Kawai, S. Yamaguchi, T. Kizuki, T. Matsushita, T. Kokubo, T. Nakamura, and S Matsuda, "Bone bonding ability of a chemically treated low elastic modulus Ti alloy; gum metal", J. Mater. Sci.; Mater. Med., vol. 25 , pp. 635-643, November 2014

[78] S. Yamaguchi, T. Matsushita, and T. Kokubo, "A bioactive Ti metal with a Ca-enriched surface layer releases $\mathrm{Mg}$ ions" $R S C$ Adv., vol. 3, pp. 11274-11282, July 2013.

[79] S. Yamaguchi, S. Nath, T. Matsushita, and T. Kokubo, "Controlled release of strontium ions from a bioactive $\mathrm{Ti}$ metal with a $\mathrm{Ca}$ enriched surface layer", Acta Biomater., vol. 10, pp. 2282-2289, May 2014

[80] S. Yamaguchi, T. Matsushita, T. Nakamura, and T. Kokubo, "Bioactive Ti metal with Ca-enriched surface layer able to release Zn ion", Key Eng. Mater., vol.529-530, pp. 547-552, November 2013.

[81] T. Kizuki, T. Matsushita, and T. Kokubo, "Antibacterial and bioactive calcium titanate layers formed on Ti metal and its alloys", J. Mater. Sci.: Mater. Med., vol. 25, pp. 1737-1746, July, 2014.

[82] M. Uchida, H. -M. Kim, T. Kokubo, K. Tanaka, and T. Nakamura, "Structural dependence of apatite formation on zirconia gels in a simulated body fluid", J. Ceram. Soc., Jpn, vol. 110, pp.710-715, August 2002

[83] M. Uchida, H. -M. Kim, F. Miyaji, T. Kokubo, and T. Nakamura, "Apatite formation on zirconium metal treated with aqueous NaOH”, Biomaterials, vol. 23, pp.313-317, January 2002.

[84] X. Chen, A. Nouri, Y. Li, J. Lin, P.D. Hodgson, and C. Wen, "Effect of surface roughness of $\mathrm{Ti}, \mathrm{Zr}$, and $\mathrm{TiZr}$ on apatite precipitation from simulated body fluid", Biotechnol. Bioeng. vol. 101, pp. 378-387, October 2008

[85] T. Miyazaki, H-M. Kim, T. Kokubo, C. Ohtsuki, and T. Nakamura, "Apatite-forming ability of niobium oxide gels in a simulated body fluid”, J. Ceram. Soc. Jpn, vol. 109, pp. 929-933, November 2001. 
[86] X. J. Wang, Y. C. Li, Y. Yamada, P. D. Hodgson, and C. E. Wen, "In vitro bioactivity evaluation of titanium and niobium metals with different surface morphologies", Acta Biomater., vol. 4, pp. 1530-1535, September 2008.

[87] T. Miyazaki, H. -M. Kim, T. Kokubo, H. Kato, and T. Nakamura, "Induction and acceleration of Bonelike apatite formation on tantalum oxide gel in simulated body fluid", J. Sol-Gel Sci. Tech., vol. 21, pp. 83-88, June 2001.

[88] T. Miyazaki, H. -M. Kim, T. Kokubo, H. Kato, and T. Nakamura, "Bioactive tantalum metal prepared by $\mathrm{NaOH}$ treatment", $J$. Biomed. Mater. Res., vol. 50, pp. 35-42, April 2000.

[89] T. Miyazaki, H. -M. Kim, T. Kokubo, F. Miyaji, H. Kato, and T. Nakamura, "Effect of thermal treatment on apatite-forming ability on $\mathrm{NaOH}$-treated tantalum metal", J. Mater. Sci.: Mater. Med., vol. 12, pp. 683-687, August 2001.

[90] T. Miyazaki, H. -M. Kim, T. Kokubo, C. Ohtsuki, H. Kato, and T. Nakamura, "Enhancement of bonding strength by graded structure at interface between apatite layer and bioactive tantalum metal", $J$. Mater. Sci.: Mater. Med., vol. 13, pp. 651-655, July 2002.

[91] T. Miyazaki, H. -M. Kim, T. Kokubo, C. Ohtsuki, H. Kato, and T. Nakamura, "Mechanism of bonelike apatite formation on bioactive tantalum metal in a simulated body fluid", Biomaterials, vol. 23, pp. 817-832, February 2002.
[92] H. Kato, T. Nakamura, S. Nishiguchi, Y. Matsusue, M. Kobayashi, T. Miyazaki, H. -M. Kim, and T. Kokubo, "Bonding of alkali- and heat-treated tantalum implants to bone", J. Biomed. Mater. Res. (Appl. Biomater.) vol. 53, pp. 28-35, 2000.

[93] K. Kawanabe, K. Ise, K. Goto, H. Akiyama, T. Nakamura, A Kaneuji, T. Sugimori, and T. Matsumoto, "A new cementless total hip arthroplasty with bioactive titanium porous-coating by alkaline and heat treatments: Average 4.8-year results", J. Biomed. Mater. Res. Part B: Appl. Biomater., vol. 90B, pp. 476-481, July 2009.

[94] K. So, A. Kaneuji, T. Matsumoto, S. Matsuda, and H. Akiyama, "Is the bone-bonding ability of a cementless total hip prosthesis enhanced by alkaline and heat treatments?", Clin. Orthop. Relat. Res., vol. 471, pp. 3847-3855, December 2013.

[95] M. Takemoto, S. Fujibayashi, M. Neo, K. So, N. Akiyama, T. Matsushita, T. Kokubo, and T. Nakamura, "A porous bioactive titanium implant for spinal interbody fusion: an experimental study using a canine model", J. Neurosurg.: Spine, vol. 7, pp. 435-443, October 2007.

[96] S. Fujibayashi, M. Takemoto, M. Neo, T. Matsushita, T. Kokubo, K. Doi, T. Ito, A. Shimizu, and T. Nakamura, "A novel synthetic material for spinal fusion: a prospective clinical trial of porous bioactive titanium metal for lumber interbody fusion", Eur. Spine J., vol. 20, pp. 1486-1495, September 2011.

Received: June 06, 2014

Revised: August 26, 2014

Accepted: August 27, 2014

(C) Kokubo and Yamaguchi; Licensee Bentham Open.

This is an open access article licensed under the terms of the Creative Commons Attribution Non-Commercial License (http://creativecommons.org/licenses/by-nc/3.0/) which permits unrestricted, non-commercial use, distribution and reproduction in any medium, provided the work is properly cited. 